\title{
A rare cause of jaundice in a case: Hydatid cyst infestation
}

\author{
Kaan Demirören ${ }^{1, *}$, Kemal Ağengin $^{2}$, Veli Avcı ${ }^{2}$, Salim Bilici ${ }^{2}$ \\ ${ }^{1}$ Department of Pediatric Gastroenterology, Yuzuncu Yil University, Dursun Odabas Medical Center, Van, Turkey \\ ${ }^{2}$ Department of Pediatric Surgery, Yuzuncu Yil University, Dursun Odabas Medical Center, Van, Turkey
}

\begin{abstract}
Although the most common cause of obstructive jaundice is viral infections, there are some rare disorders which can cause this picture. We present a 15 -year-old girl, admitted with an obstructive jaundice. Her laboratory tests including viral infections were normal. The diagnosis of hydatid cyst was performed with both ultrasonography and indirect hemagglutination assay. The patient was operated on and hydatid cyst was seen to be ruptured into the choledochus. In conclusion, nonviral causes of hepatitis are less common, but must be considered in the differential diagnosis. An important complication of hydatid disease is rupture to biliary tree. This situation may cause obstructive jaundice.
\end{abstract}

Key Words: Jaundice, hydatid cyst, choledochus, hepatitis

\section{Introduction}

Acute hepatitis is characterized by inflammation and necrosis of the liver. The underlying triggering factor for the inflammatory process may be toxic, autoimmune, infective or metabolic. Although the most common cause of obstructive jaundice is viral infections, there are some rare disorders which can cause this picture. One of them is a hydatid cyst infestation (1). We reported a rare case presented with obstructive jaundice and diagnosed as hydatid cyst infestation.

\section{Case report}

A 15-year-old girl was admitted to our clinic with complaints of jaundice and abdominal pain. Physical examination revealed hepatomegaly $(4 \mathrm{~cm}$ palpable at the costal margin), and icter. Splenomegaly was not present. The results of laboratory tests were as follows: Hemoglobin 10.3 $\mathrm{g} / \mathrm{dL}$; leukocyte $11,300 / \mathrm{mL}$; platelet $463,000 / \mathrm{mL}$; alanine aminotransferase (ALT) $103 \mathrm{IU} / \mathrm{L}$; aspartate aminotransferase (AST) $77 \mathrm{U} / \mathrm{L}$; total bilirubin $22 \mathrm{mg} / \mathrm{dL}$; direct bilirubin $18.8 \mathrm{mg} / \mathrm{dL}$; total protein $5.8 \mathrm{~g} / \mathrm{dL}$; albumin $2.4 \mathrm{~g} / \mathrm{dL}$; alkaline phosphatase $1625 \mathrm{IU} / \mathrm{L}$. Prothrombin time, partial thromboplastin time, and INR levels were normal. Anti-hepatitis A virus (HAV) immunoglobulin (Ig) $G$ was positive, and anti-HAV IgM was negative. Other viral tests for hepatitis B, hepatitis C, cytomegalovirus, Epstein-Barr virus, parvovirus
B19 did not indicate an acute infection. C-reactive protein was $117 \mathrm{mg} / \mathrm{L}$ (range: $0-5 \mathrm{mg} / \mathrm{L}$ ).

Abdominal ultrasonograhy revealed a cyst, in the segment 4 of liver with $7 \times 5 \mathrm{~cm}$ in diameter, and a dilated choledochal diameter $(15 \mathrm{~mm})$. Then, abdominal computerized tomography was performed and it was commented that a hydatid cyst was ruptured into choledochus (Figure 1). Indirect hemagglutination test for hydatid cyst was positive.

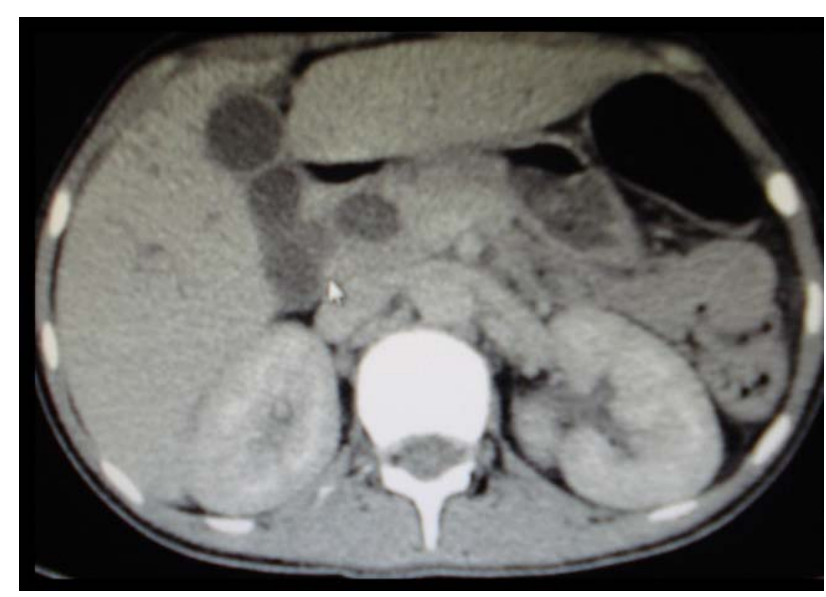

Fig. 1. Computerized tomography shows a hydatid cyst and dilated choledochus.

Therefore, the patient was operated on. In operation, hydatid cyst was seen to be ruptured into choledochus. Cholecystectomy, choledocotomy, removal of cyst membranes 
which obstructed choledochus and drainage procedures were administered. Any complication did not develop. Albendazole treatment was begun at a dose of $400 \mathrm{mg} /$ day. Seven days after the operation, the laboratory tests improved (ALT 32 $\mathrm{IU} / \mathrm{L}$; total bilirubin $3 \mathrm{mg} / \mathrm{dL}$; direct bilirubin 2 $\mathrm{mg} / \mathrm{dL}$ ) and the patient was discharged.

\section{Discussion}

Hydatid disease, a zoonotic infection, is caused by adult or larval stages of cestodes belonging to the genus Echinococcus and the family Taeniidae (2). Human infection with Echinococcus granulosus may occur after ingestion of ova excreted by infected dogs. Dogs generally acquire infection via consumption of sheep liver or intestine containing hydatid cysts (3). Ingestion of eggs typically occurs after the handling of an infected $\operatorname{dog}$ or the drinking of contaminated water. The ingested embryo, after release from the egg in the duodenum, penetrates the intestinal mucosa and enters the portal circulation (3).

Hydatid disease is still an important public health problem in many endemic countries. While it can develop anywhere in the human body, the liver and the lungs are the most frequent locations (13 ). Other sites of infection in approximately $10 \%$ of children include the brain, bones, genitourinary tract, eyes, spleen, and heart (3). Our case had a cyst solely in the liver.

Infestation is common in childhood, although symptoms may not occur for many years (3). Hepatic cysts are usually slow growing and lead to asymptomatic hepatomegaly, but may manifest due to secondary infection or greatening in size (1). Hepatic involvement is marked by the development of cysts within the hepatic parenchyma, most often within the right lobe $(3,4)$. Hydatid cyst of our case within the left lobe (Segment 4). Typically, the cyst is surrounded by a fibrous capsule. An acellular, hyalinized layer forms the exocyst, underlaid by a germinal layer. Extrusions of the germinal layer form brood capsules which contain protoscolices. Hydatid sand, composed of separated brood cysts and protoscolices, floats within the main cyst cavity. Septation may occur, as may formation of daughter cysts (3).

A common complication of hepatic hydatid disease is the rupture of the cyst caused by the increased pressure within it. Cysts may rupture into the biliary tree, the peritoneal or pleural cavity, the pericardium, the gastrointestinal tract, or even into blood vessels (5). Hydatid disease was reported as noncomplicated in $46.3 \%$ of the patients. The most common complications were reported intrabiliary rupture $(34.4 \%)$, cyst infection $(32.7 \%)$, and their combination $(24.5 \%)$ (6).

Hydatid cyst rupture into the biliary tree may involve the common hepatic duct, lobar biliary branches, or the small intrahepatic bile ducts. In such cases, the suggestion of the diagnosis may be obtained by ultrasonography (7). Intrabiliary rupture can occur with two different clinical picture: Occult communication (10\%-64\%) and frank intrabiliary rupture $(3 \%-35 \%)$. The occult rupture is usually silent and may be accompanied by suppuration or it can progress to a frank rupture. In the frank rupture, daughter vesicles and fragmented membranes escape into the biliary tree causing obstruction, cholangitis or septicemia $(5,8,9)$. Communications with the biliary system were reported to be encounter in $21 \%$ of the patients with hepatic hydatid cyst. A history of jaundice had been taken in $25 \%$ of them (8).

In the diagnosis of liver hydatid cysts, abdominal ultrasonography was reported to give correct diagnosis in $94 \%$ of the patients (9). Indirect hemagglutination assay confirms the diagnosis in $80 \%$ to $94 \%$ of hepatic hydatidosis cases (10). In a study (11), hepatic cystic echinococcosis was detected in $0.3 \%$ by ultrasonography, while $8.9 \%$ and $10.1 \%$ of the cases were found to be positive for cystic echinococcosis by ELISA and indirect hemagglutination, respectively. In our case, the diagnosis of hydatid cyst had been confirmed with both ultrasonography and indirect hemagglutination assay. Albendazole has been known to be a useful choice in the management of cystic echinococcosis both when used as sole treatment or as an adjunct to surgery (12).

In conclusion, nonviral causes of hepatitis are less common, but must be considered in the differential diagnosis. An important complication of hydatid disease is rupture to biliary tree. This situation may cause obstructive jaundice. Therefore, abdominal ultrasonography must be performed in differential diagnosis for a case presenting with obstructive jaundice.

\section{References}

1. Davison S. Acute Hepatitis. In: Kelly A (ed). Diseases Of The Liver and Biliary System in Children (2nd ed). Oxford: Blackwell, 2004, pp 92106. 
2. Yıldız B, Şen S, Bal ZŞ, et al. Epidemiological, Laboratory and Clinical Features of Childhood Hydatid Disease. J Pediatr Inf 2013; 7: 53-56.

3. Novak DA, Lauwers GY, Kradin RL. Bacterial, parasitic, and fungal infections of the liver. In: Suchy FJ, Sokol RJ, Balistreri WF (eds). Liver Disease in Children (3rd ed). New York: Cambridge University Press, 2007, pp 871-896.

4. Mirshemirani A, Khaleghnejad A, Kouranloo J, et al. Liver Hydatid Cyst in Children (A 14-year Review). Iran J Pediatr 2011; 21: 385-389.

5. Michalopoulos N, Laskou S, Papavramidis TS, et al. Rupture of right hepatic duct into hydatid cyst. J Korean Med Sci 2012; 27: 953-956.

6. Symeonidis $\mathrm{N}$, Pavlidis $\mathrm{T}$, Baltatzis $\mathrm{M}$, et al. Complicated liver echinococcosis: 30 years of experience from an endemic area. Scand J Surg 2013; 102: 171-177.
7. Martí-Bonmatí L, Menor F, Ballesta A. Hydatid cyst of the liver: rupture into the biliary tree. AJR Am J Roentgenol 1988; 150: 1051-1053.

8. Atli M, Kama NA, Yuksek YN, et al. Intrabiliary rupture of a hepatic hydatid cyst: associated clinical factors and proper management. Arch Surg 2001; 136: 1249-1255.

9. Tomuş C, Iancu C, Pop F, et al. Intrabiliary rupture of hepatic hydatid cysts: results of 17 years' experience. Chirurgia (Bucur) 2009; 104: 409-413.

10. Biava MF, Dao A, Fortier B. Laboratory diagnosis of cystic hydatic disease. World J Surg 2001; 25: 10 14.

11. Kilimcioğlu AA, Ozkol M, Bayindir P, et al. The value of ultrasonography alone in screening surveys of cystic echinococcosis in children in Turkey. Parasitol Int 2006; 55: 273-275.

12. Horton RJ. Albendazole in treatment of human cystic echinococcosis: 12 years of experience. Acta Trop 1997; 64: 79-93. 